\title{
СУБ- И НАНОСЕКУНДНЫЕ ДИОДНЫЕ ИСТОЧНИКИ СВЕТА
}

\author{
(C) 2020 г. Е. С. Воропай, Ф. А. Ермалицкий, \\ А. Е. Радько, М. П. Самцов \\ Поступила в редакцию 13.08.2019 г. \\ После доработки 13.08.2019 г. \\ Принята к публикации 14.08.2019 г.
}

DOI: $10.31857 / \mathrm{S} 0032816220010097$

Разработанные суб- и наносекундные полупроводниковые источники излучения предназначены для различных оптоэлектронных устройств, где необходимы повторяющиеся короткие световые импульсы. Они могут быть использованы в импульсной спектрометрии, флуорометрии (для измерения кинетики различных видов люминесценции), дальнометрии (в качестве зондирующих излучателей) и т.д.

Источники света состоят из блока оптического излучателя и внешнего блока питания. Оптические излучатели могут работать в режиме как внутреннего, так и внешнего запуска. Достоинствами приборов являются компактность, а также низкие уровни питания (12 В) и потребляемой мощности (3 Вт).

Блок оптического излучателя включает в себя задающий генератор, цепь синхронизации, низковольтный формирователь суб- и наносекундных электрических импульсов, цепь накачки излучателя на основе подстраиваемого источника постоянного тока, а также светоизлучатель - лазерный диод (или светодиод).

Задающий генератор обеспечивает необходимую частоту следования импульсов тока, частота может регулироваться ступенчато или плавно. Специальная цепь формирует импульсы синхронизации для внешних устройств регистрации, она позволяет иметь при необходимости дополнительную задержку относительно импульса синхронизации. Низковольтный формирователь выдает наносекундный перепад напряжения $\sim 12$ В, который цепью дифференцирования преобразуется в импульс напряжения длительностью порядка 1 нс. После инвертирования данный импульс через эмиттерный повторитель поступает непосредственно на светоизлучатель. Для оптимизации режима работы светоизлучателя - лазерного диода или светодиода - имеется регулируемый источник постоянного тока. Для оптимизации пара- метров излучаемых световых импульсов (длительности и световой мощности) для каждого типа диодов обеспечивается подбор тока накачки. В качестве светоизлучательных элементов использовались лазерные диоды и светодиоды фирм SONY и SONYO.

Наружный сетевой блок-адаптер 220 В/12 В × $\times 0.25$ А (обычно промышленного производства) обеспечивает излучатель необходимым напряжением питания 12 В.

Технические характеристики диодных источников света. Излучатель может функционировать в двух вариантах: лазерном и светодиодном (в зависимости от типа полупроводникового светоизлучателя):

- лазерный вариант (на основе лазерных диодов): длина волны излучения от 405 до 808 нм; длительность импульсов на полувысоте от 0.8 нс; световая мощность до 10 мВт;

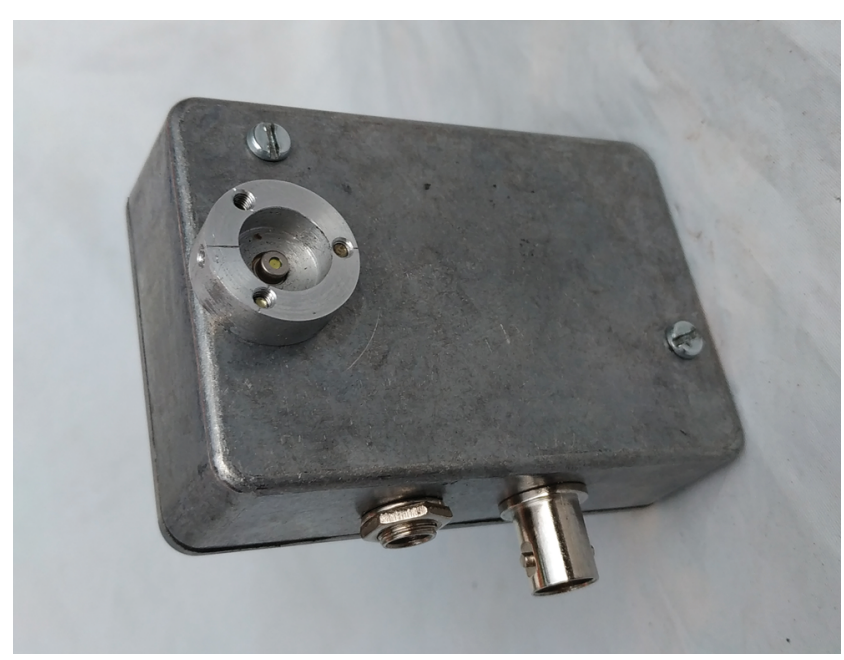

Рис. 1. Внешний вид диодных источников. 
- светодиодный вариант (на основе светодиодов): длина волны излучения от 245 до 575 нм; длительность импульсов на полувысоте от 1.6 нс; световая мощность до 1 мВт.

Частота следования световых импульсов до 5 МГц. Размеры блока излучателя $190 \times 150 \times 30$ мм. Питание от серийного блока питания 220 В/12 В × $\times 0.25$ А, потребляемая мощность 3 Вт. Масса 0.2 кг.
Общий вид диодных источников приведен на рис. 1.

Адрес для справок: Республика Беларусь, 220045, Минск, ул. Курчатова, 7, Институт прикладных физических проблем имени А.Н. Севченко (НИИПФП им. А.Н. Севченко БГУ), тел. +375-29-1113183, факс: +375-17-398-03-31, e-mail:f.ermalitski@gmail.com 